Article

\title{
Emissions and Air Quality Implications of Upstream and Midstream Oil and Gas Operations in Mexico
}

\author{
Elena McDonald-Buller ${ }^{1, *}$, Gary McGaughey ${ }^{1}$, John Grant ${ }^{2}{ }^{2}$, Tejas Shah ${ }^{2}{ }^{\mathbb{D}}$, Yosuke Kimura ${ }^{1}$ \\ and Greg Yarwood ${ }^{2}$ (D) \\ 1 Center for Energy and Environmental Resources, Air Resources Engineering Program, \\ Cockrell School of Engineering, The University of Texas at Austin, 10100 Burnet Road, Building EME (\#133), \\ MC: R7100, Austin, TX 78758, USA; garym@mail.utexas.edu (G.M.); yosuke@austin.utexas.edu (Y.K.) \\ 2 Ramboll, 7250 Redwood Boulevard, Suite 105, Novato, CA 94945, USA; jgrant@ramboll.com (J.G.); \\ TShah@ramboll.com (T.S.); gyarwood@ramboll.com (G.Y.) \\ * Correspondence: ecmb@mail.utexas.edu
}

check for

updates

Citation: McDonald-Buller, E.; McGaughey, G.; Grant, J.; Shah, T.; Kimura, Y.; Yarwood, G. Emissions and Air Quality Implications of Upstream and Midstream Oil and Gas Operations in Mexico. Atmosphere 2021, 12, 1696. https:// doi.org/10.3390/atmos12121696

Academic Editors: Yun Zhu, Jim Kelly, Jun Zhao, Jia Xing and Yuqiang Zhang

Received: 22 November 2021 Accepted: 13 December 2021 Published: 17 December 2021

Publisher's Note: MDPI stays neutral with regard to jurisdictional claims in published maps and institutional affiliations.

Copyright: (c) 2021 by the authors. Licensee MDPI, Basel, Switzerland. This article is an open access article distributed under the terms and conditions of the Creative Commons Attribution (CC BY) license (https:// creativecommons.org/licenses/by/ $4.0 /)$.

\begin{abstract}
Mexico approved amendments to its constitution in December 2013 that initiated transformational changes to its energy sector. This study developed a 2016 bottom-up emissions inventory for volatile organic compounds (VOCs), nitrogen oxides $\left(\mathrm{NO}_{\mathrm{x}}\right)$, sulfur dioxide $\left(\mathrm{SO}_{2}\right)$, carbon monoxide (CO), and fine particulate matter $\left(\mathrm{PM}_{2.5}\right)$ from upstream and midstream sector sources, including onshore and offshore well sites, gas flaring, natural gas processing facilities, and natural gas compressor stations, throughout Mexican basins. Crude oil storage tanks at onshore oil well sites and venting and fugitive sources at offshore oil production sites were the primary sources of VOC emissions. Key contributions to $\mathrm{NO}_{x}, \mathrm{CO}$, and $\mathrm{PM}_{2.5}$ emissions were from internal combustion engines at offshore oil well sites and midstream operations. $\mathrm{SO}_{2}$ emissions were associated with onshore and offshore gas flaring and boilers and process heaters at natural gas processing facilities. Application of the inventory with the Comprehensive Air Quality Model with Extensions (CAMx) indicated that oil and gas production operations could contribute to ozone and $\mathrm{PM}_{2.5}$ concentrations in Mexican and U.S. states under favorable transport patterns. This study provides a foundation for assessing the implications of Mexico's future energy policies on emissions and domestic and cross-border air quality and public health.
\end{abstract}

Keywords: Mexico; energy reform; oil; natural gas; emissions inventory; energy systems; ozone

\section{Introduction}

Mexico has been among the world's major exporters of crude oil, which has been crucial to its economy. Oil production peaked in 2004 with the supergiant Cantarell field in the southern Gulf of Mexico but has declined by $50 \%$ since then [1] due to constraints in investment resources and technical expertise required to fully exploit its hydrocarbon resources [2]. Energy reform was part of the Pacto por México that required amendments to the Mexican Constitution approved in December 2013 with secondary implementing legislation in 2014 [2-4]. A significant outcome was the allowance for private and foreign investment and participation under different contract modalities for oil and gas exploration and extraction, which had previously been restricted to the state-owned oil company Petróleos Mexicanos (Pemex), Mexico City, Mexico [2-4]. Between 2015 and 2018, Mexico awarded more than 100 contracts to companies within Mexico and 19 other countries for exploration and extraction of its onshore, shallow water, and deepwater hydrocarbon resources [5], which remain the property of the nation [4]. Following a transition in presidential administrations in December 2018, national priorities have emphasized energy sovereignty and increasing oil production and refining capacity with the prioritization and strengthening of Pemex [6,7]. 
Mexico and other oil producing nations are challenged with navigating a complex energy landscape with global transitions toward renewable energy sources and decarbonization expected in the coming years [8]. Mexico unconditionally committed to reducing greenhouse gas emissions by $22 \%$ and black carbon emissions by $51 \%$ by 2030 relative to the baseline business-as-usual scenario as part of its Nationally Determined Contributions from the Paris Agreement in 2015 under the United Nations Framework Convention on Climate Change (UNFCCC) [9]. In 2018, Mexico issued federal guidelines for the prevention and control of methane emissions from its hydrocarbons sector [10]. In November 2021, Mexico, and leading oil and gas producing nations such as the United States, Saudi Arabia, Canada, Brazil, Iraq, and Nigeria, joined the Global Methane Pledge commitment to reduce methane emissions by at least 30 percent from 2020 levels by 2030 [11].

These developments have implications for Mexico's emissions profiles and air quality. In addition to greenhouse gas emissions, oil and gas production is a source of volatile organic compounds (VOCs), nitrogen oxides $\left(\mathrm{NO}_{\mathrm{x}}\right)$, sulfur dioxide $\left(\mathrm{SO}_{2}\right)$, carbon monoxide $(\mathrm{CO})$, and particulate matter (PM), and can contribute to the formation of tropospheric ozone [12-16]. These criteria pollutants and precursors present human health and ecological risks [17-22]. A growing body of studies have focused on the spatial proximity of populations to upstream oil and gas development and adverse birth, cardiovascular, respiratory, hematological, and immunological health outcomes [23-33]. Strategies aimed at reducing greenhouse gas emissions have the potential to achieve co-reductions in common emission sources of other pollutants such as VOCs [12].

This study developed a bottom-up emissions inventory for VOCs, $\mathrm{NO}_{x}, \mathrm{SO}_{2}, \mathrm{CO}$, and fine particulate matter $\left(\mathrm{PM}_{2.5}\right)$ from upstream and midstream sector sources, including onshore and offshore well sites, gas flaring, natural gas processing facilities, and natural gas compressor stations for the 2016 base year across Mexican basins as a foundation for assessing future national policies and oil and gas production activity. We found previous bottom-up emissions estimates of these pollutants in Mexico within the public domain to be limited and to differ in spatial coverage, emission sources, and temporal resolution [34-38]. Earlier inventories have also represented time periods with different oil and gas production volumes in Mexico. The 2016 base year coincided with the National Collaborative Emissions Modeling Platform developed by the U.S. Environmental Protection Agency (EPA) and U.S. states [39]. The inventory was applied with the Comprehensive Air Quality Model with Extensions (CAMx) to examine contributions of onshore and offshore oil and gas producing regions in Mexico to ozone and $\mathrm{PM}_{2.5}$ concentrations in Mexican states and U.S. border regions.

\section{Methods}

\subsection{Upstream Emissions}

Figure 1 shows the locations of 10,458 wells active during 2016 by basin [40]. Annual oil and gas production volumes were 788,738 thousand barrels (Mbbl) and 2,127,142 million cubic feet (MMcf) [40]. Offshore production in the shallow waters ( $<500 \mathrm{ft})$ of the Sureste Basin, which include the Ku-Maloob-Zaap (KMZ), Cantarell, Abkatún-Pol-Chuc, and Litoral de Tabasco fields, accounted for nearly $80 \%$ of total national oil production and $54 \%$ of natural gas production [40]. Onshore oil production is located in the Sureste and TampicoMisantla basins. Most non-associated gas production occurs in the Burgos, Veracruz, and Sureste basins [41], and accounted for 22\% of domestic production in 2016 [42].

Bottom-up emissions estimates were developed using activity metrics and per unit activity-based emission factors for the upstream and midstream sector sources addressed in this study. For onshore basins in Mexico, locations and activity metrics, including active well counts, oil and gas production volumes, and spud counts, were obtained from Mexico's National Hydrocarbons Commission (CNH) [40]. Activity metrics were mapped to U.S. source classification codes (SCCs) associated with onshore oil and gas operations (Table S1). An oil well was classified as having a gas-oil production ratio (GOR) $<6000 \mathrm{cf} / \mathrm{b}$ and conversely for a natural gas well [43]. Because well site equipment configurations 
across Mexican basins were not readily available, activity metrics for Mexico were applied with emission factors developed for onshore basins in Texas that had similar operations and hydrocarbon resources. Texas-based emission control assumptions were removed as a conservative estimate. The Sabinas and Burgos basins share a common border with the Western Gulf Basin, and primarily include legacy vertical wells producing natural gas with no condensate production. Emission factors for these Mexican basins (Table S2) were based on emission estimates in the U.S. Environmental Protection Agency (EPA) National Emissions Inventory (2014NEIv2) [44] normalized by oil and gas production from the EPA Oil and Gas Emission Estimation Tool [45] for the Western Gulf Basin. Emission factors for the Tampico-Misantla, Veracruz, and Sureste basins (Table S3), which include legacy vertical wells producing both oil and natural gas, were based on the Palo Duro Basin using a similar approach.

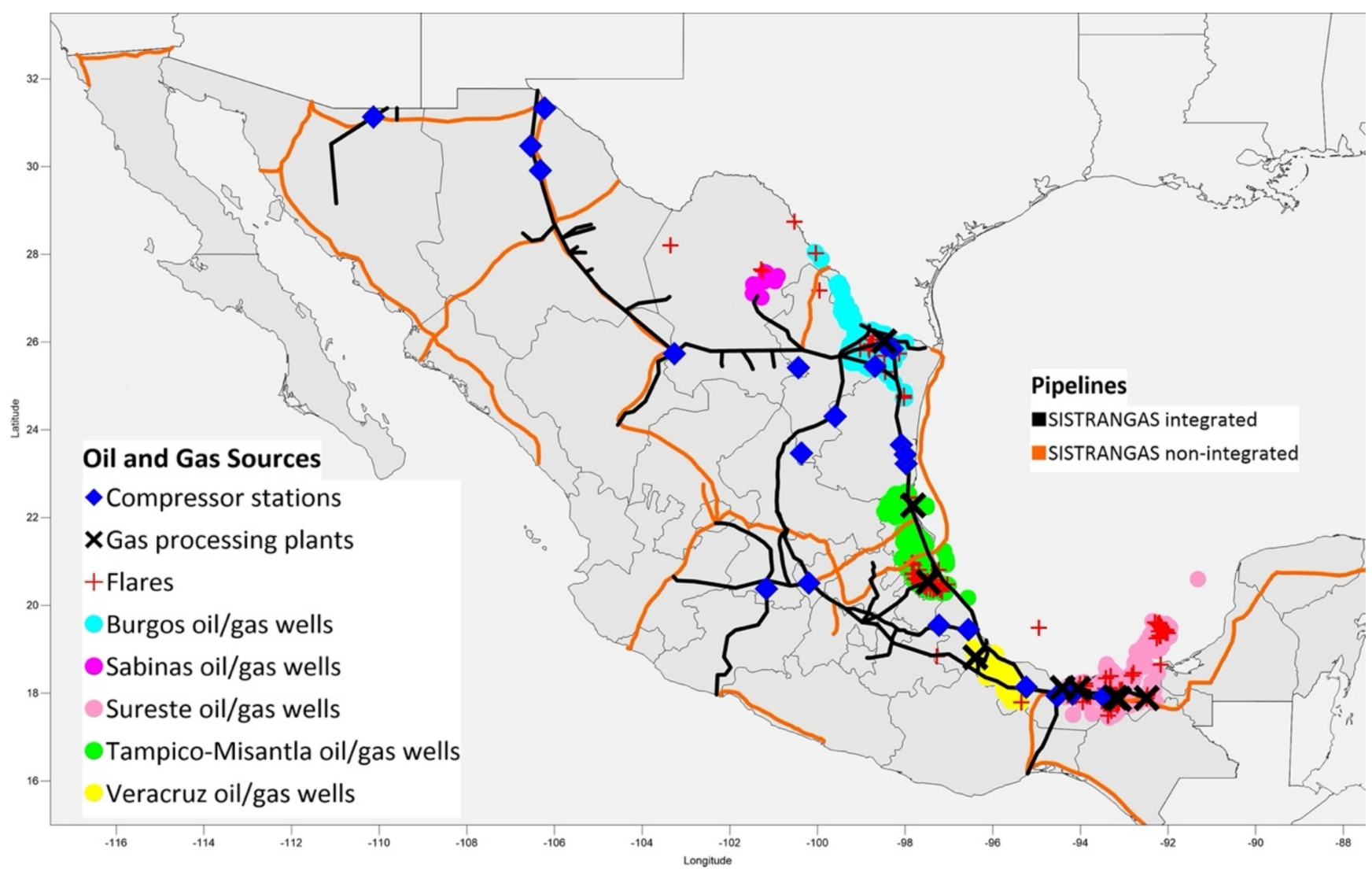

Figure 1. Upstream and midstream oil and gas sector emission sources in Mexico during 2016 including well sites by basin, flares, natural gas processing plants, and natural gas compressor stations along pipelines within Mexico's Integrated National Natural Gas Transportation and Storage System (SISTRANGAS).

Offshore wells in Mexico produced oil and gas during 2016, with the exception of less than $1 \%$ in the Tampico-Misantla Basin, which produced only natural gas. Activity from offshore shallow water platforms was based on oil and/or gas production volumes from the CNH. Emission factors were developed using emissions [46] and production data for shallow water leases with gas or oil and gas production under the jurisdiction of the U.S. Bureau of Ocean Energy Management [47] in 2014 (Table S4). The analysis included only those leases with a GOR between 0 to $130 \mathrm{Mcf} / \mathrm{bbl}$ for consistency with the range reported by the CNH for offshore oil production wells in the Sureste Basin during 2016.

Shah et al. [48] identified flaring locations and flared gas volume from Visible Infrared Imaging Radiometer Suite (VIIRS) Nightfire (VNF) detections that were applied with emission factors from the EPA's AP-42 compilation [49] and Oil and Gas Emission Estimation Tool [45] to estimate emissions in 2012. VNF detections with black body temperatures 
$>1400$ K during May 2016 [50] showed good spatial agreement with the locations of flaring activity in the Sureste Basin identified by Shah et al. [48]. Projection factors were developed from CNH onshore and offshore gas production volumes [40] to estimate emissions in 2016.

\subsection{Midstream Emissions}

Pemex [42] identified eleven natural gas processing facilities (Figure 1) in operation during 2016. Eight were included in the 2008 Mexico National Emissions Inventory [51], and emissions were projected based on the ratio of 2016 and 2008 natural gas intake volumes from Pemex [42]. Locations of the remaining three facilities were identified from the North American Cooperation on Energy Information (NACEI) [52]. Emissions were estimated using linear regressions between facility-wide emissions and 2016 petrochemical production from the eight INEM facilities reported by Pemex [42].

Figure 1 shows 22 central compressor stations in operation along SISTRANGAS pipelines [53]. Mexico's Ministry of Energy [54] and Eduardo [55] reported installed horsepower for 18 of the 22 compressor stations. The average installed horsepower across the 18 compressors was assumed for the four that lacked information. In the absence of station-specific engine type data, AP-42 [49] emission factors for uncontrolled 4-stroke rich burn engines were applied with installed horsepower to estimate emissions for each of the 22 compressor stations.

\subsection{Air Quality Modeling Configuration}

This study adapted a CAMx air quality modeling platform from the Texas Commission on Environmental Quality [56], which was based on the 2016v1 National Collaborative Emissions Modeling Platform [39]. CAMx is an open-source Eulerian photochemical grid modeling system for gas and particulate air pollution that has been applied across a range of spatial and temporal scales to support air quality research and regulatory assessments throughout the world [57]. The $36 \mathrm{~km} \times 36 \mathrm{~km}$ horizontal domain included most of Canada, the continental United States, and almost all of Mexico (Figure S1). Simulations were conducted for the 15 December 2015-1 January 2017 time period. The modeling configuration is described further by McDonald-Buller et al. [58]. Point source emissions for Mexico's upstream and midstream oil and gas sectors (NAICS categories 211110, 325110, 221210) and electricity sector (NAICS 221110) were replaced with our estimates; all other emissions remained identical. CAMx simulations examined the contributions of midstream sources and different geographic regions with upstream oil and gas operations to maximum daily $8 \mathrm{~h}$ average (MDA8) ozone concentrations and $24 \mathrm{~h}$ average $\mathrm{PM}_{2.5}$ concentrations across Mexican states and U.S. border regions using an emissions zero-out approach.

\section{Results and Discussion}

\subsection{Base Year Emissions Profiles}

Annual emission estimates from onshore and offshore well sites, flaring, natural gas processing facilities, and natural gas compressor stations for 2016 are shown in Figure 2. Total $\mathrm{NO}_{\mathrm{x}}, \mathrm{CO}, \mathrm{VOC}, \mathrm{SO}_{2}$, and $\mathrm{PM}_{2.5}$ emissions from these sources across Mexican basins were approximately $355,000,427,000,869,000,141,000$ and 5100 tons, respectively. Figure 3 shows the disaggregated contributions of emissions from offshore oil well and onshore oil and gas well sites and natural gas processing facilities by SCC-based categories in order to assess contributions to the annual totals shown in Figure 2. Emissions from flaring and natural gas compressor stations were each represented by a single SCC category, as described above. 


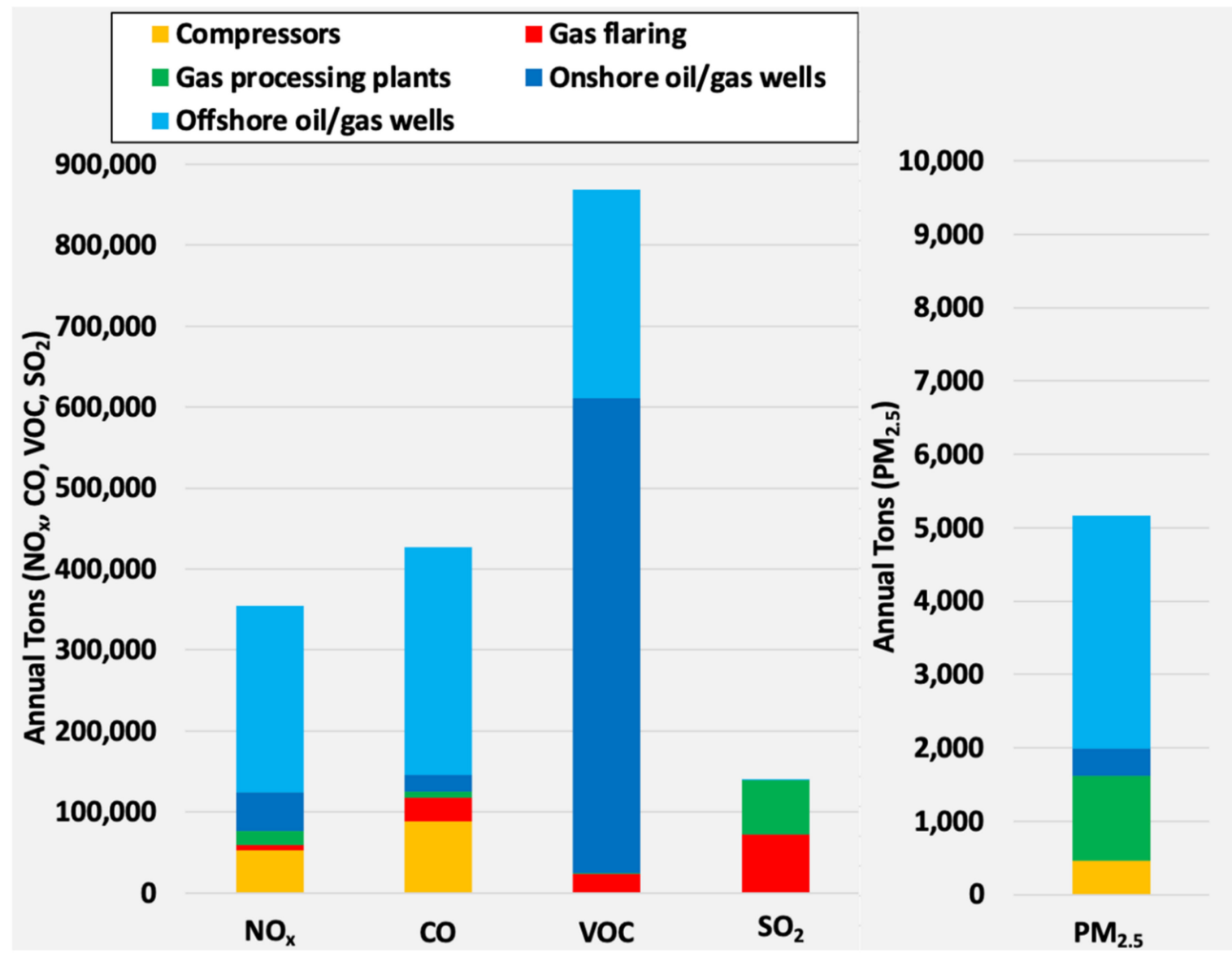

Figure 2. Annual estimates of $\mathrm{NO}_{\mathrm{x}}, \mathrm{CO}, \mathrm{VOC}, \mathrm{SO}_{2}$, and $\mathrm{PM}_{2.5}$ emissions (tons) from onshore and offshore oil and gas well sites, flaring, natural gas processing plants, and natural gas compressor stations in 2016.

Offshore and onshore well site operations accounted for $69 \%-78 \%$ of the total annual $\mathrm{NO}_{\mathrm{x}}, \mathrm{CO}$, and $\mathrm{PM}_{2.5}$ emissions, as shown in Figure 2, with the largest contributions from offshore oil production coming from the Sureste Basin (Figure S2). Natural gas and diesel-fired internal combustion engines at offshore oil well production sites (Figure 3a) contributed $55 \%-65 \%$ of total $\mathrm{NO}_{x}, \mathrm{CO}$, and $\mathrm{PM}_{2.5}$ emissions. Natural gas-fired compressor engines at onshore gas well sites (Figure $3 b$ ), primarily in the Burgos and Sureste basins, accounted for $11 \%$ of total $\mathrm{NO}_{x}$ emissions. Gas-fired internal combustion engines at compressor stations contributed $15 \%$ of total $\mathrm{NO}_{x}$ and $21 \%$ of total $\mathrm{CO}$ emissions. Approximately $22 \%$ of total $\mathrm{PM}_{2.5}$ emissions were attributed to natural gas-fired boilers and turbines (Figure 3c) at natural gas processing facilities.

Onshore and offshore well site operations in the Sureste and Tampico-Misantla basins (Figure S2) were the primary sources of VOC emissions. Crude oil storage tanks from onshore oil well site operations (Figure 3d) accounted for $63 \%$ of total VOC emissions. Collectively, well casing vents and fugitive sources from offshore oil production (Figure 3a) in the Sureste Basin accounted for $28 \%$ of total VOC emissions.

Gas flaring and natural gas-fired boilers and process heaters at natural gas processing facilities contributed $52 \%$ and $47 \%$, respectively, of total $\mathrm{SO}_{2}$ emissions, as shown in Figure 2. Almost all $\mathrm{SO}_{2}$ emissions from natural gas processing were concentrated in the onshore region of the Sureste Basin, which includes the Nuevo Pemex, Ciudad Pemex, and Cactus facilities in the states of Tabasco and Chiapas. $\mathrm{SO}_{2}$ emissions from flaring occurred offshore (59\%) and onshore (24\%) in the Sureste Basin and onshore in the Tampico-Misantla Basin $(15 \%)$, as shown in Figure S2. 
(a)

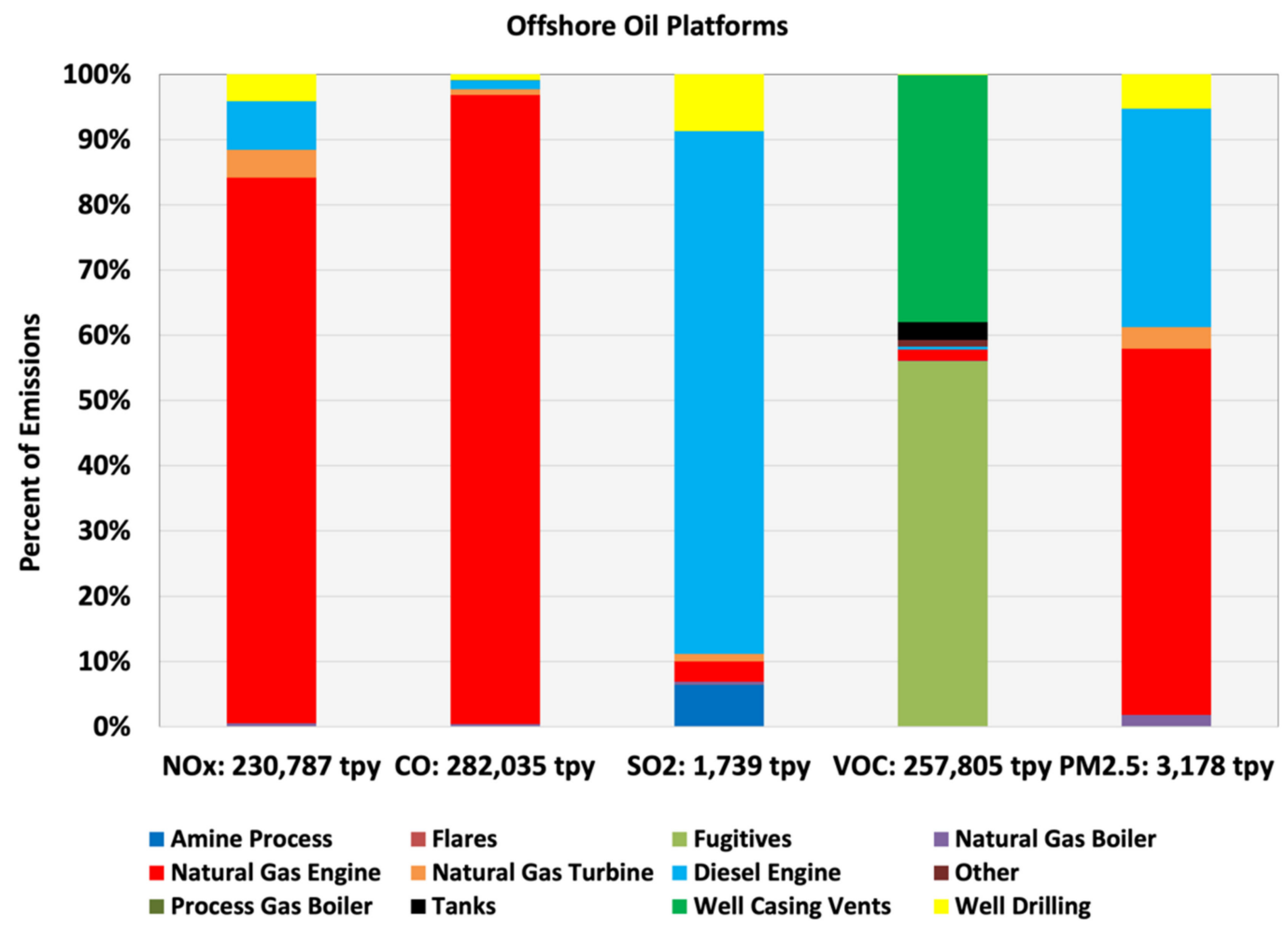

(b)

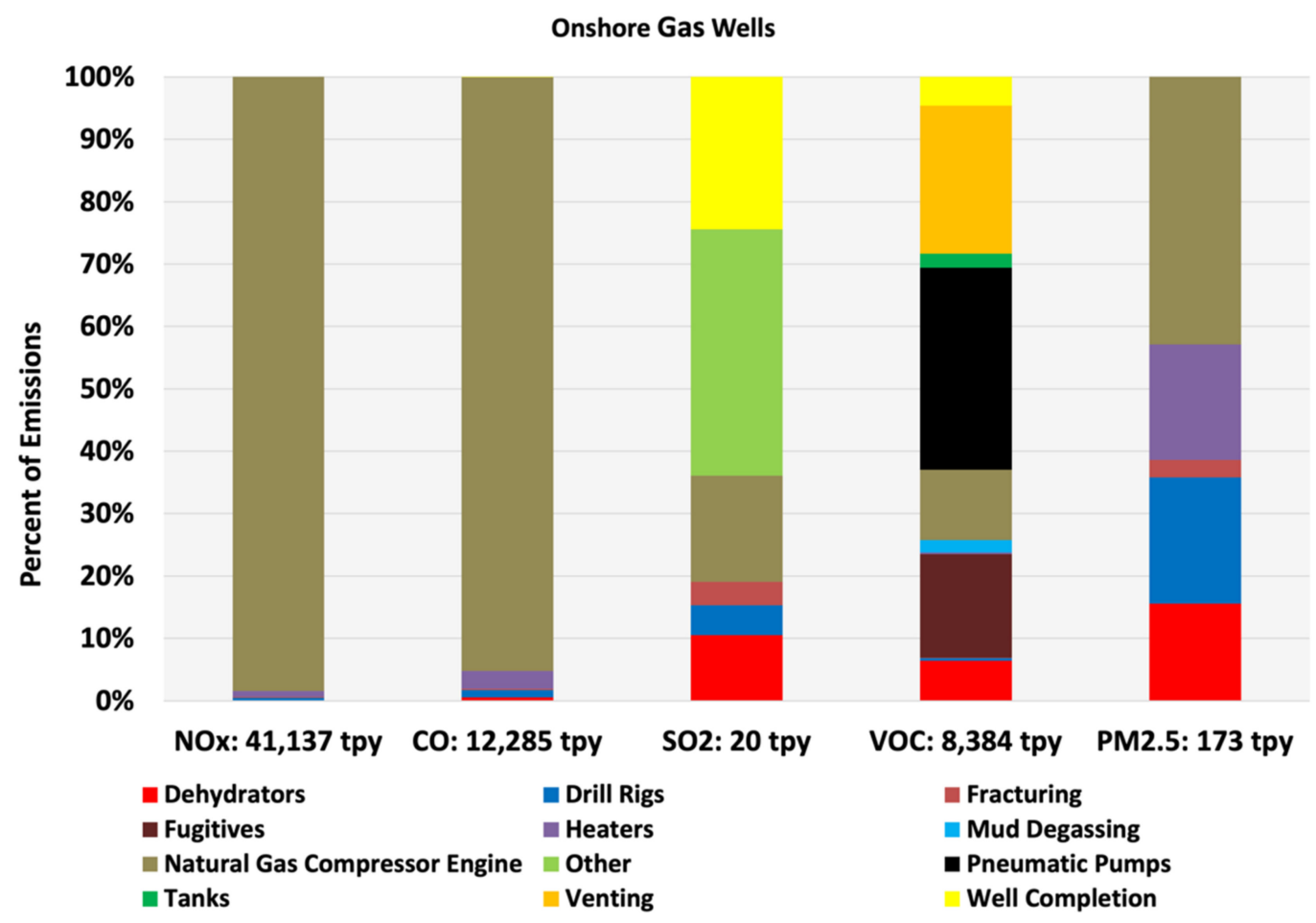

Figure 3. Cont. 
(c)

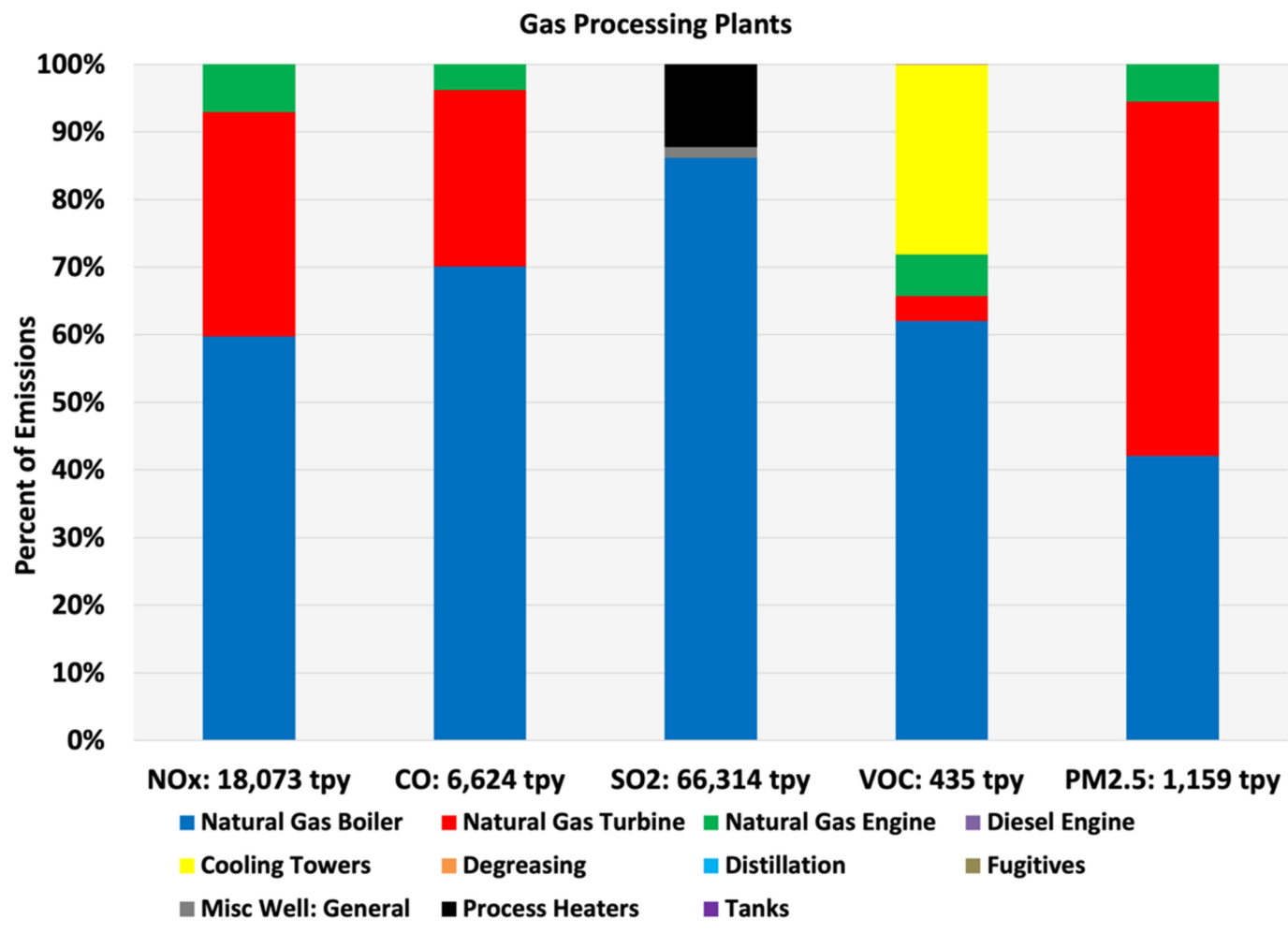

(d)

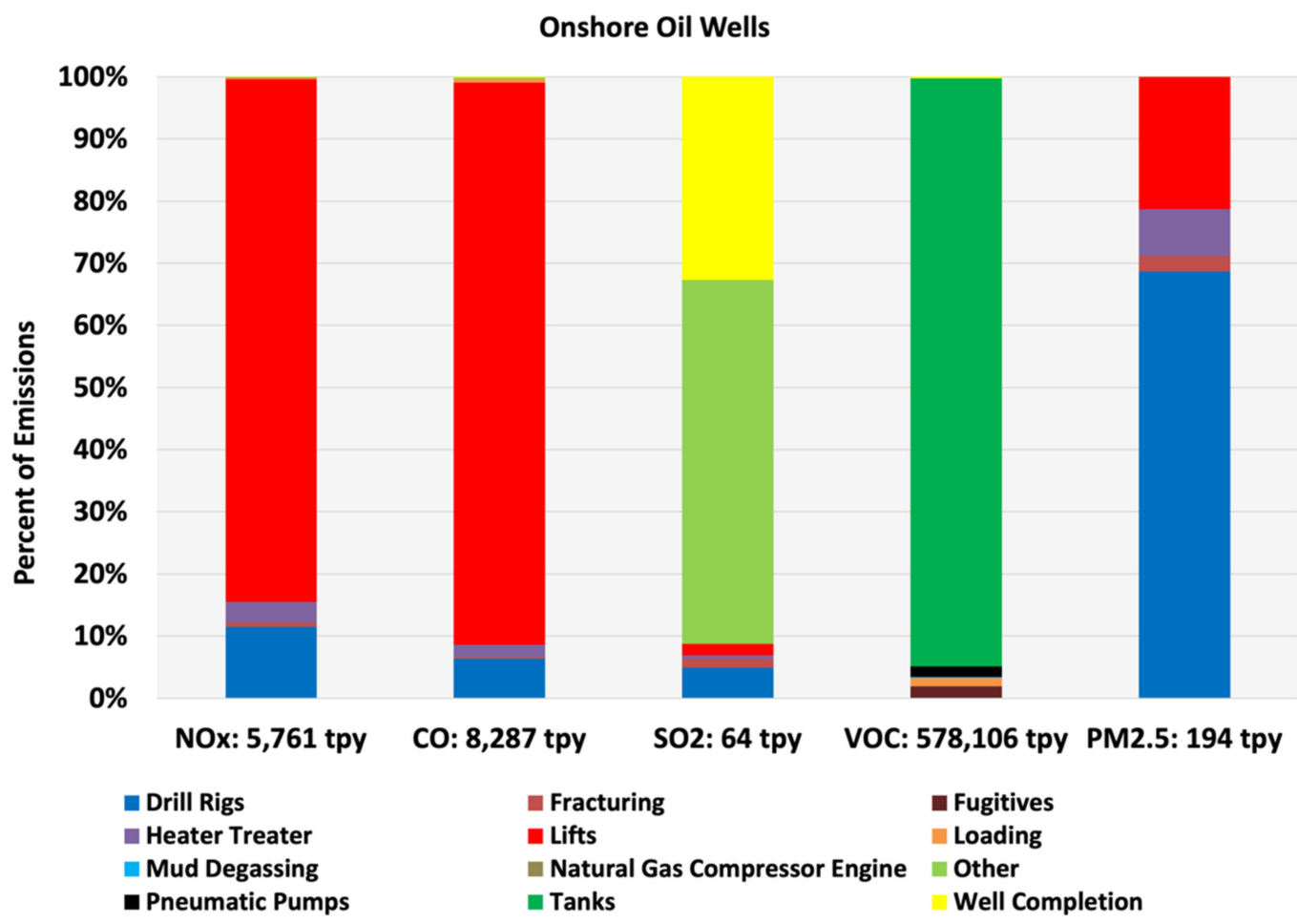

Figure 3. Contributions from (a) offshore oil wells, (b) onshore gas wells, (c) natural gas processing facilities, and (d) onshore oil wells by SCC-based source categories to $\mathrm{NO}_{\mathrm{x}}, \mathrm{CO}, \mathrm{SO}_{2}, \mathrm{VOC}$, and $\mathrm{PM}_{2.5}$ emissions in 2016. 


\subsection{Intercomparison of Emission Source Contributions}

Key sources of criteria pollutant and precursor emissions identified by previous studies are similar to those found in our study, although these studies spanned time periods with different oil and gas production volumes and likely operational practices in Mexico. Most of these studies had a geographic focus on operations in the Bay of Campeche (Sureste Basin), in particular those in the northeastern region associated with the Cantarell and KMZ fields. Several bottom-up studies were conducted circa 1999-2006. Villaseñor et al. [34] attributed 63-79\% of $\mathrm{SO}_{x}, \mathrm{CO}$, and nonmethane hydrocarbons (NMHC) emissions to Cantarell platforms, with the offshore Cayo de Arcas terminal and Dos Bocas terminal in Tabasco identified as the largest sources of $\mathrm{NO}_{\mathrm{x}}$. Schifter et al. [35] found flaring and combustion sources, including process heaters, boilers, and diesel engines, to be the primary sources of $\mathrm{NO}_{\mathrm{x}}, \mathrm{SO}_{\mathrm{x}}, \mathrm{CO}, \mathrm{HC}$, and $\mathrm{PM}$ emissions. Mendoza-Domínguez and Graniel-Peralta [36] identified seasonal differences in extraction and operational processes and meteorological conditions that contributed to low flare combustion efficiencies. Bottomup emissions estimates associated with the Nuevo Pemex, Cuidad Pemex, Cactus, and La Venta natural gas processing facilities were developed by Bauer et al. [37]. Among the dominant contributions to emissions were sulfur recovery units as sources of $\mathrm{SO}_{2}$, compression stations as sources of $\mathrm{CO}$ and $\mathrm{NO}_{x}$, boilers and power generation as sources of $\mathrm{NO}_{\mathrm{x}}$, and oil batteries and compression stations as sources of total hydrocarbons.

Our examination indicated that the magnitude and spatial distribution of $\mathrm{SO}_{2}$ and $\mathrm{NO}_{\mathrm{x}}$ emissions of Mexico's offshore oil and gas operations in the Sureste Basin were not represented in the more recent Emissions Database for Global Atmospheric Research (EDGAR) version 5.0 bottom-up inventory [59-62]. Missing emissions or large underrepresentation of these emissions is an important, persistent gap that has also been noted by Zhang et al. [63] in the EDGAR version 4.3.1 inventory.

We compared our bottom-up emission estimates with those in the 2016v1 National Collaborative Emissions Modeling Platform, which represented an interpolation of 2014 and 2018 projections of the 2008 INEM [39]. Upstream oil and gas well sites in the 2016v1 platform shown in Figure S3 were sparse relative to those identified in our study. Nationwide $\mathrm{VOC}, \mathrm{CO}$, and $\mathrm{NO}_{\mathrm{x}}$ emissions in the 2016v1 platform from upstream sources were lower than our estimates (Table S5). In contrast, emissions of $\mathrm{SO}_{2}$ in the 2016v1 inventory were greater, with $96 \%$ of the nationwide upstream sector total attributed to a single offshore location in the Sureste Basin possibly intended to represent the Cantarell and/or KMZ complexes. Compressor stations along SISTRANGAS pipelines, as well as three natural gas processing facilities, La Congrejera, Parajitos, and Morelo, were not included in the 2016v1 platform.

A recent bottom-up study by ICF [64] identified vented emissions (e.g., offshore venting, stranded gas venting, venting from oil tanks and condensate tanks), fugitives, and flaring as sources of methane emissions from Mexico's oil and natural gas industry and significant opportunities for abatement. Top-down approaches have applied airborne- or satellite-based measurements to examine emission trends in the Sureste Basin. Fioletev et al. [65] attributed changes in an offshore $\mathrm{SO}_{2}$ hotspot between 2005-2007 and 2008-2010 to rising production of heavier crude oil in the KMZ fields as Cantarell declined. A secondary $\mathrm{SO}_{2}$ onshore hotspot was attributed to the Nuevo Pemex gas processing center. Zhang et al. [63] found annual $\mathrm{SO}_{2}$ and $\mathrm{NO}_{2}$ emission rates between 2005-2017 over the $\mathrm{KMZ}$ and Cantarell offshore production cluster peaked in 2008 and have declined since due to expanded capacity for associated gas utilization, which reflects policy interventions to reduce flaring. Zavala-Ariaza et al. [66] suggested that associated gas from offshore production is being transported and flared at onshore midstream facilities. Inaccurate assumptions regarding flaring efficiencies in the Mexican national greenhouse gas inventory contributed to overestimation of methane emissions offshore but underestimation of emissions from Nuevo Pemex. 


\subsection{Improving Contemporary Inventories}

Current country-specific data are an ongoing need for refining bottom-up emissions inventories for Mexico. Activity metrics and locations of oil and gas sector emission sources were available through the mining of data from Mexico's federal agencies and cooperative international initiatives, but emission factors in this and prior studies have been drawn from U.S. resources, including the EPA and BOEM. In assessments of earlier bottom-up inventories, Muriel-García et al. [38] noted the needs for emission measurements and the homogenization of emission factors. Zavala-Ariaza et al. [66] suggested the main driver for inaccuracies in the Mexican greenhouse gas inventory to be the use of emission factors that are not specific to Mexico.

Uncertainties identified in this study included oil and gas well site process and equipment configurations, temporal variations in emissions, and emission control technologies and strategies across Mexican basins.

Mexico has been among the world's top countries for gas flaring $[67,68]$. Flare combustion efficiencies and smoke formation are influenced by factors such as the heating values and chemical compositions of flared gases, as well as operating practices (e.g., air or steam assisting) [69-73], and these should be more fully characterized in Mexico. CNH issued guidelines for the avoidance or reduction of natural gas flaring and venting in 2008 that led to investments in gas treatment and handling and reinjection capacity by Pemex [68]. Guidelines issued in 2016 focused on implementing methods for measuring associated gas flaring and maximizing gas utilization and conservation by operators $[67,68]$. Federal guidelines targeting methane emissions in 2018 included specifications for the efficiency of destruction equipment [10].

Although the U.S. BOEM inventory [47] included non-platform emissions (e.g., mobile vessels, helicopters, pipelaying operations), we did not extrapolate for Mexico. Nonplatform emissions are dependent on spatial domain and travel patterns, which were not expected to be consistent between the U.S. and Mexico. All offshore activity in Mexico during 2016 occurred in shallow waters. It was not feasible to isolate non-platform emissions in the BOEM inventory associated with shallow water platforms. Information collection using an approach similar to the Gulfwide Offshore Activities Data System (GOADS) by BOEM would facilitate development or refinement of these emissions in Mexico.

\section{Air Quality Impacts and Implications of Future Development}

CAMx predictions provided a perspective on the contributions of upstream and midstream sector emission sources to air quality across the Mexican states and U.S. border regions shown in Figure 4. Percentile differences in MDA8 ozone and $24 \mathrm{~h}$ average $\mathrm{PM}_{2.5}$ concentrations by region from zeroing all upstream and midstream emissions relative to the 2016 base case are shown in Figure 5. Spatial patterns in the differences in MDA8 ozone and $24 \mathrm{~h} \mathrm{PM} 2.5$ concentrations were found to be similar.

Emissions from offshore well sites in the Sureste Basin were the primary influences on MDA8 ozone and $\mathrm{PM}_{2.5}$ concentrations among the source types and regions considered in this study. Figure 6 and Figure S4 indicate that these emissions potentially contribute to air quality throughout other areas of Mexico, as well as in U.S. states such as Texas under favorable transport patterns. Impacts on average occur in states along or near Mexico's eastern coastline, including Tabasco, Oaxaca, Chiapas, Veracruz, and Tamaulipas.

The HYSPLIT forward trajectories initiated offshore within the Sureste Basin, as shown in Figure 7, illustrate how seasonal differences in transport patterns contributed to the spatial footprint of MDA8 ozone and $\mathrm{PM}_{2.5}$ impacts in downwind areas during 2016 as predominantly southeasterly wind flow patterns in the spring shifted to northeasterly by the fall. 


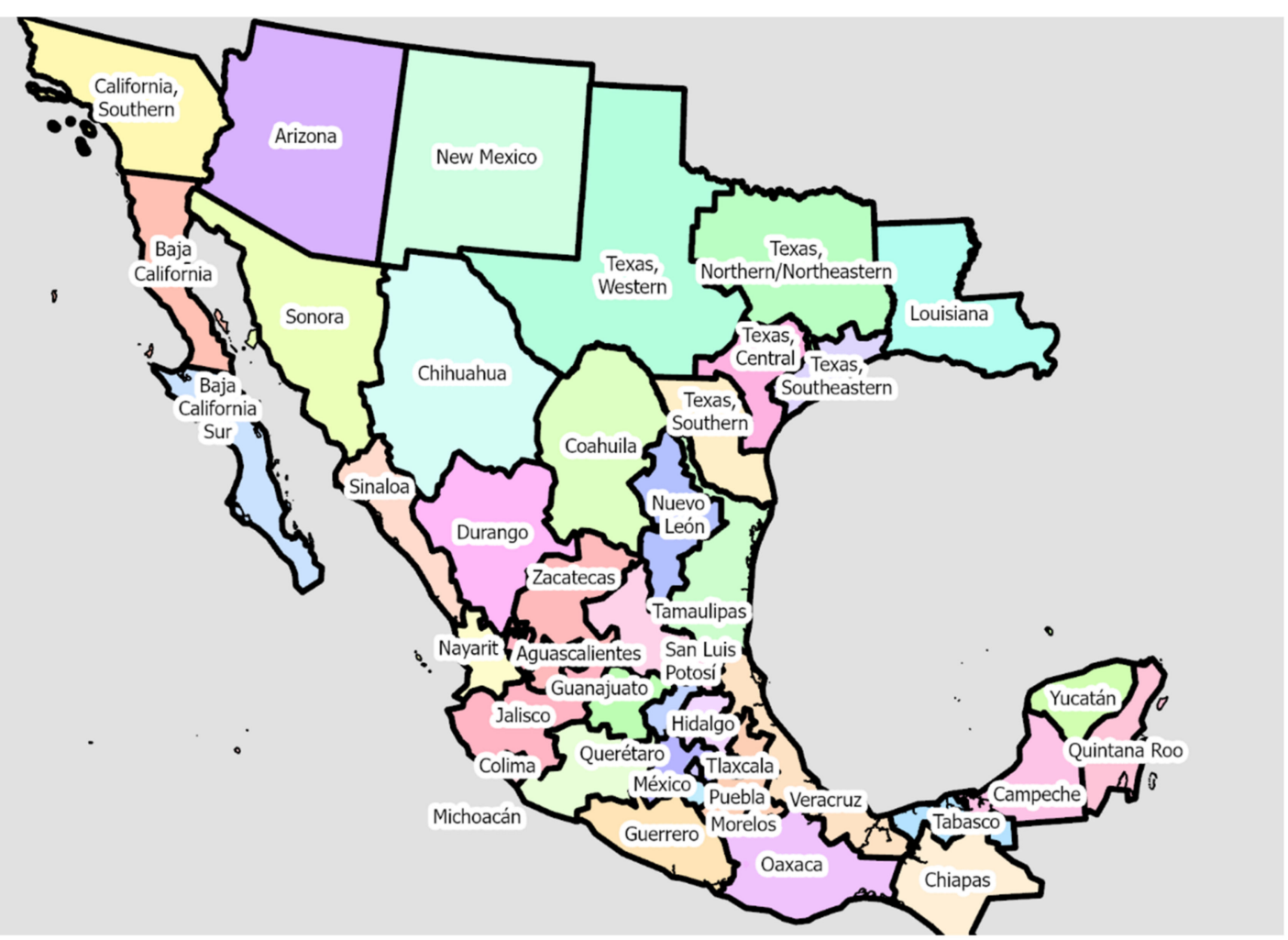

Figure 4. Mexican states and U.S. border regions included in the assessment of air quality impacts.
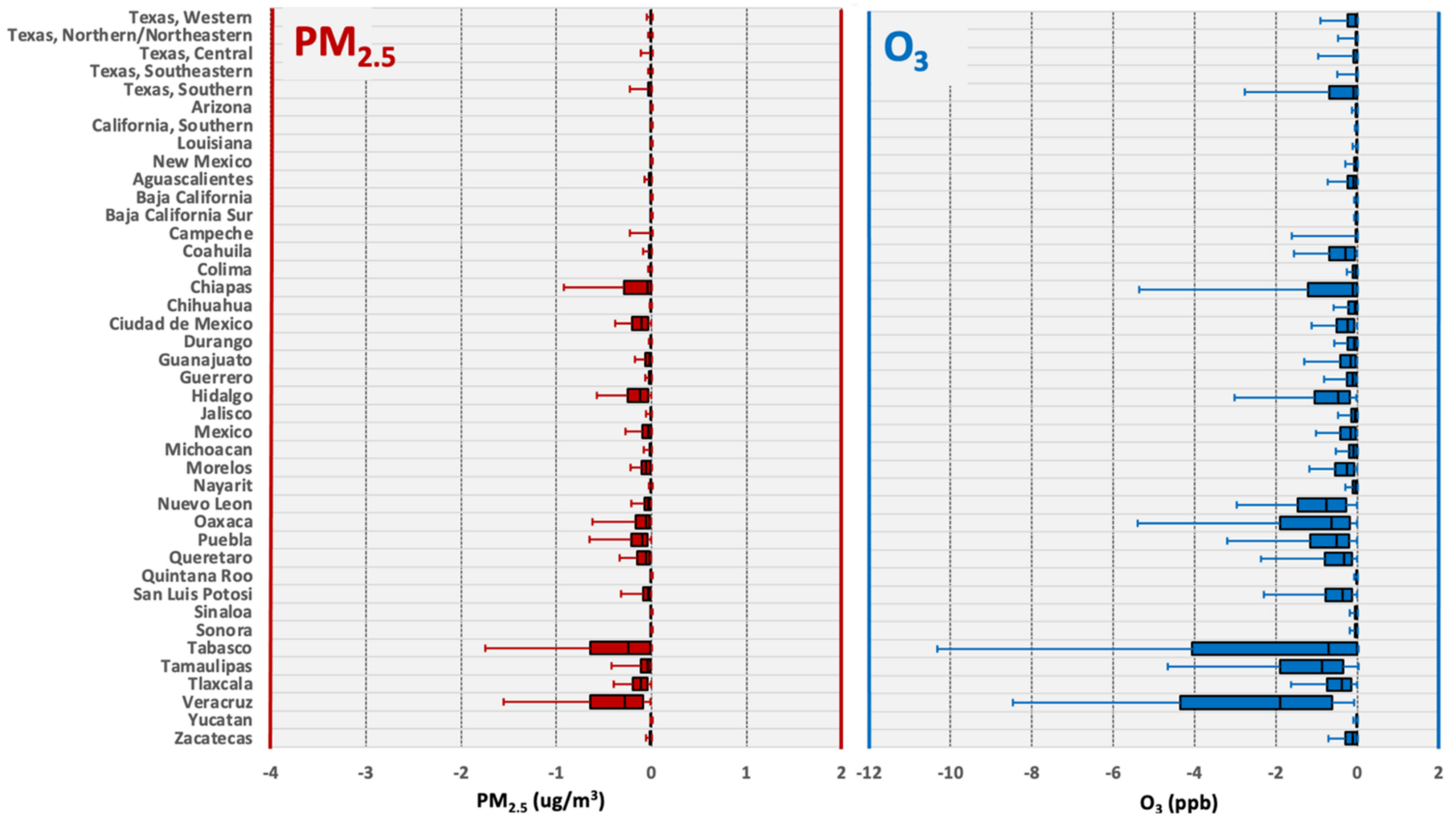

Figure 5. Annual differences in $24 \mathrm{~h}$ average $\mathrm{PM}_{2.5}$ (left) and MDA8 ozone (right) concentrations by region when upstream and midstream emission sources were zeroed relative to the base case in 2016. Boxes show the median and interquartile range (25th and 75th percentiles). Left and right whiskers extend to the 5th and 95th percentiles, respectively. 


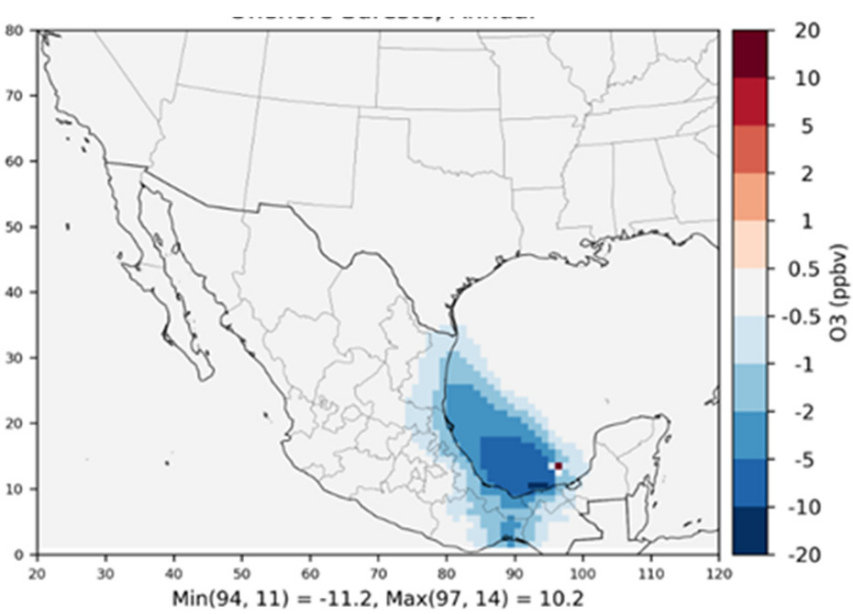

(a)

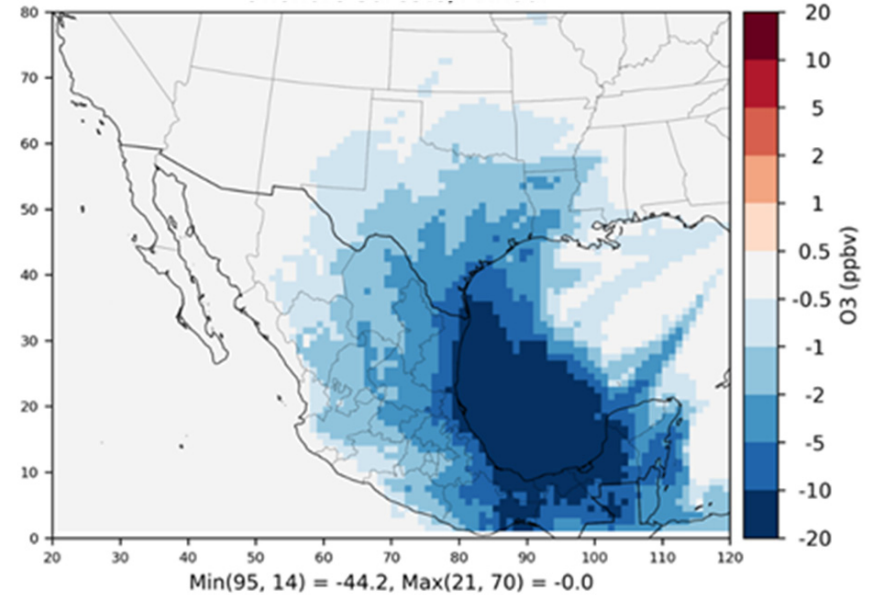

(b)

Figure 6. Predicted annual (a) average and (b) maximum differences in MDA8 ozone concentrations by grid cell when emissions from offshore well sites in the Sureste Basin were zeroed relative to the 2016 base case. Negative values indicate reductions in concentrations relative to the base case and vice versa.

Emissions from onshore oil and gas well sites in the Tampico-Misantla, Veracruz, and Burgos and Sabinas basins, as shown in Figure S5, had more modest impacts on MDA8 ozone concentrations. Activity in the Burgos/Sabinas Basin could influence air quality in Texas during southeasterly transport patterns. Onshore upstream sources in the Sureste Basin and midstream sources, as shown in Figure S5, typically had localized ozone impacts in Tabasco and southern Veracruz, but could also contribute to MDA8 ozone concentrations in states along Mexico's eastern coastline.

(a)

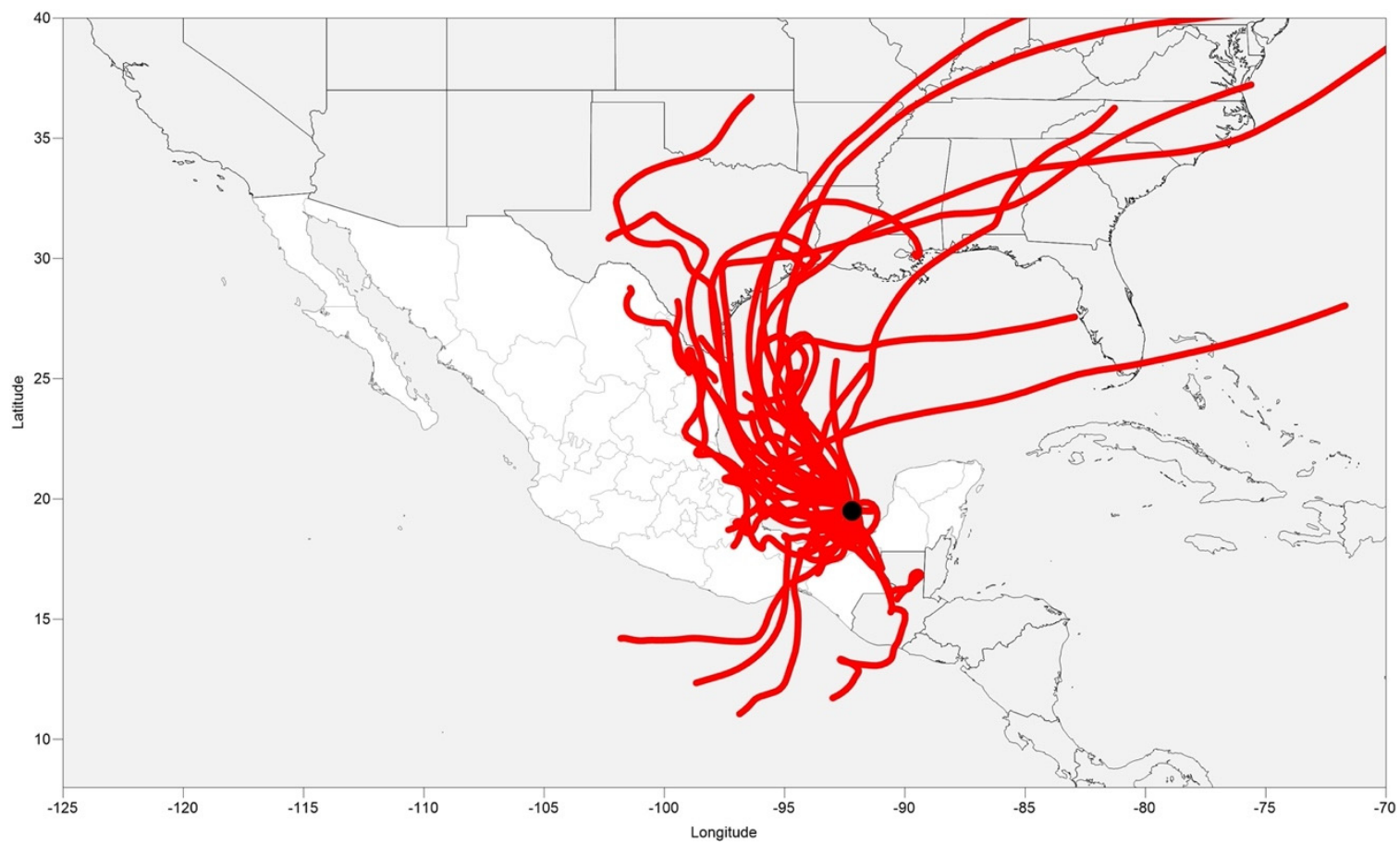

Figure 7. Cont. 
(b)

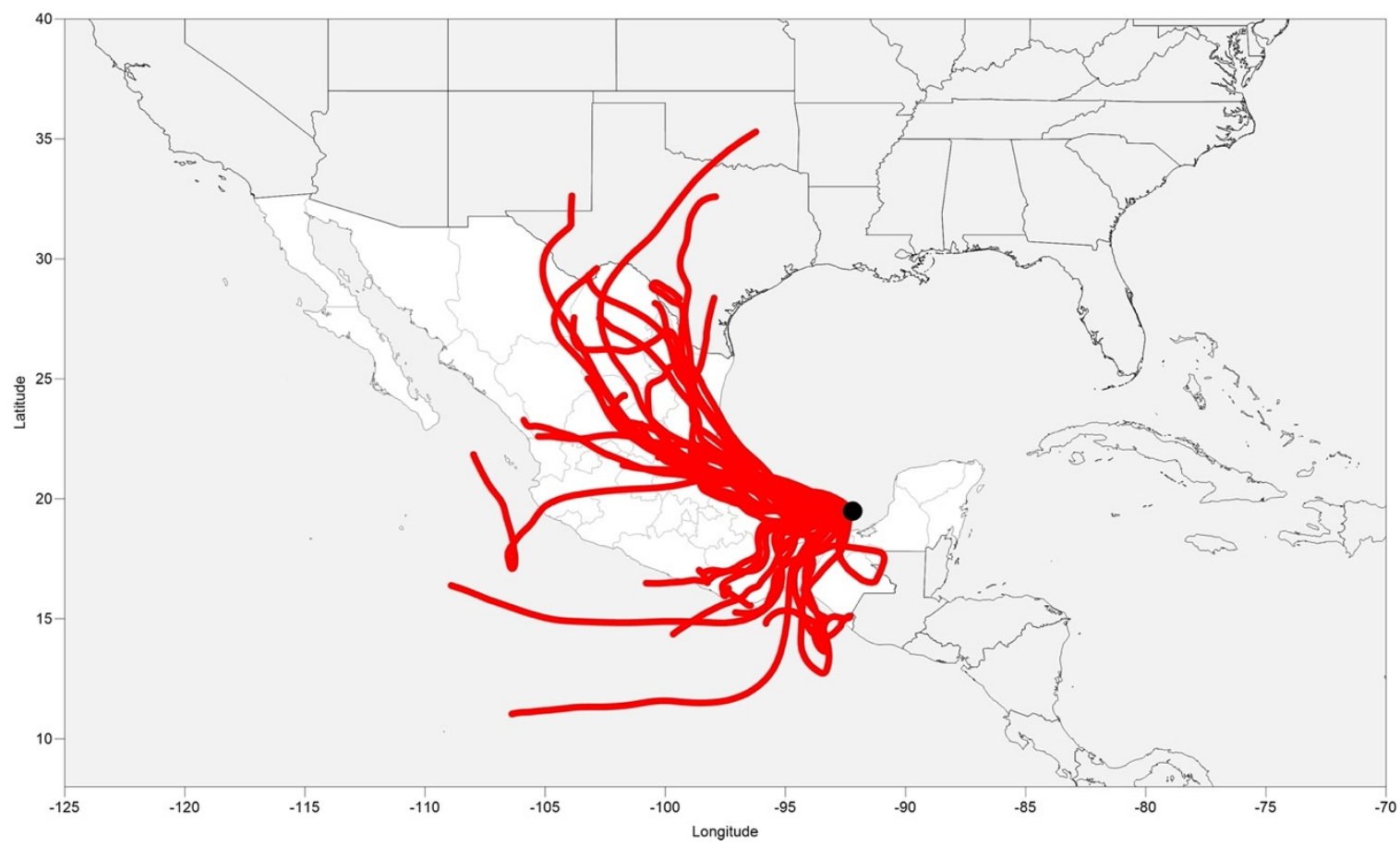

(c)

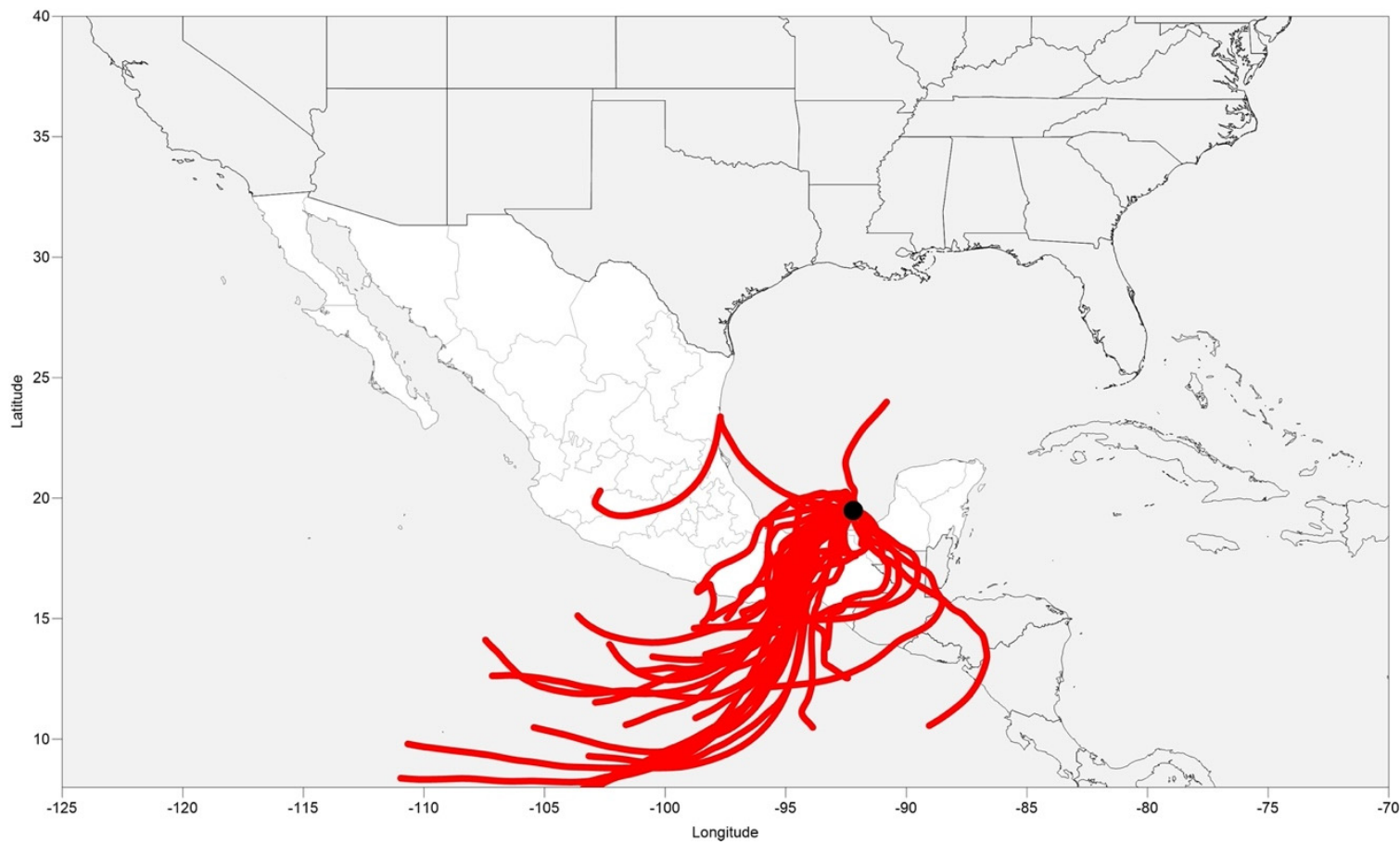

Figure 7. Daily HYSPLIT forward trajectories initiated at $500 \mathrm{~m}$ AGL at $1 \mathrm{pm}$ local time offshore within the Sureste Basin during (a) March, (b) August, and (c) November 2016.

Mexico conducted nine bidding cycles between 2015-2018 for the onshore, shallow water and deepwater blocks shown in Figure 8, which attracted domestic and international private sector investment [5]. Following a transition in presidential administrations, a moratorium was placed on future rounds, accompanied by a renewed focus on Pemex. Projects awarded under previous rounds have continued. The $\mathrm{CNH}$ reported production from 33 contracts during September 2021 (137.8 Mbpd of oil; 213.3 MMcfpd of natural gas) [5]. 
Although uncertainty for the future direction of private sector participation has increased, Figure 8 provides an indication of key geographic locations where future oil and gas production could expand depending on investment and technical resources. For example, the Zama oil field discovery (Round 1.1, Block 7) announced in July 2017 represented one of the largest shallow water discoveries in the world over the last 20 years (approximately 670-1010 MMboe [74]). Mexico has so far not pursued substantial development of its unconventional resources, although it has become increasingly reliant on U.S. pipeline imports of natural gas for its electricity sector. The Burgos Basin has promising technically recoverable shale gas resources [4] that could be poised for development, similar to the Eagle Ford Shale in Texas, if current policies change.

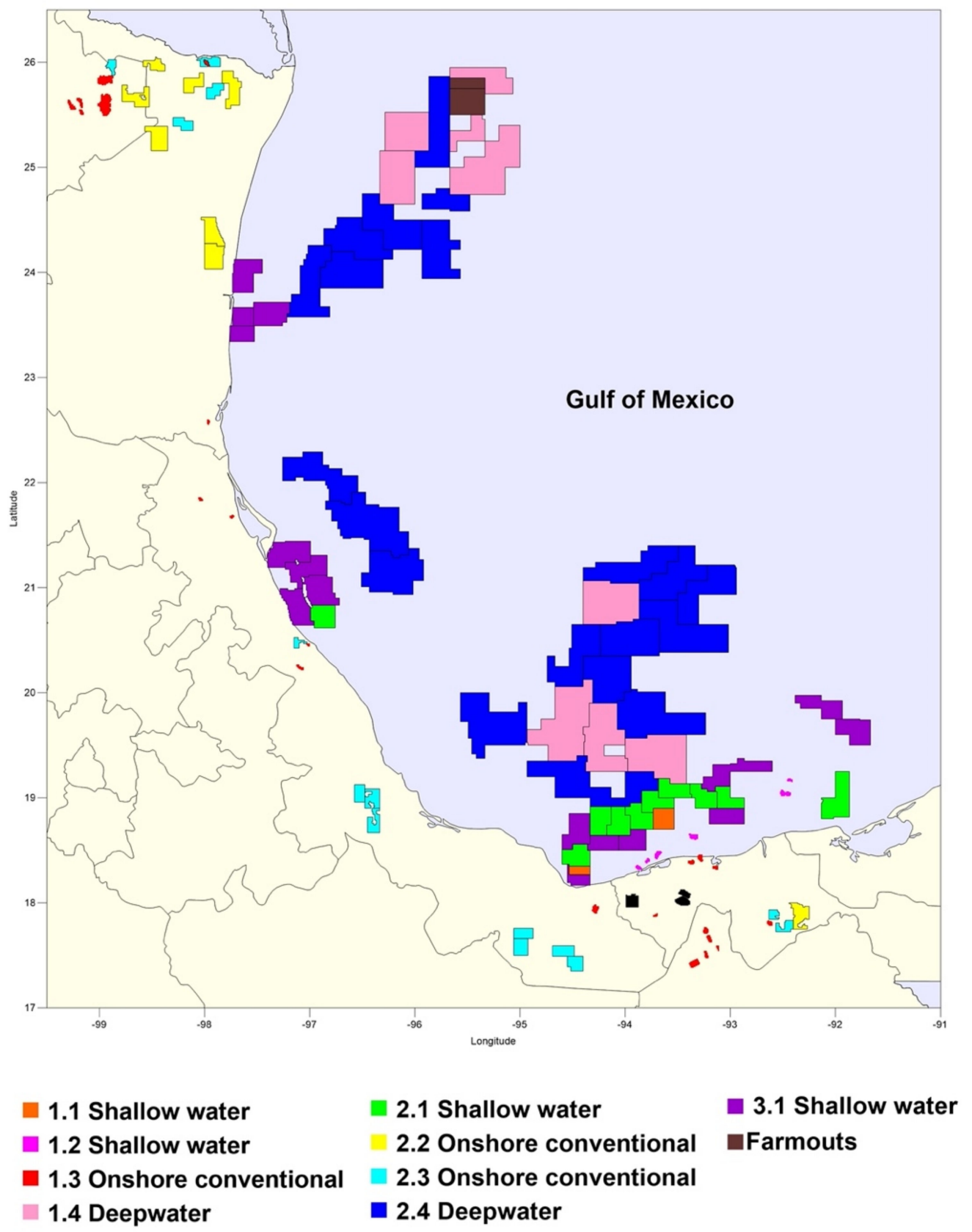

Figure 8. Awarded exploration and extraction blocks by bid round between 2015-2018. 


\section{Conclusions}

This study developed a 2016 bottom-up emissions inventory for VOCs, $\mathrm{NO}_{\mathbf{x}}, \mathrm{SO}_{2}$, $\mathrm{CO}$, and $\mathrm{PM}_{2.5}$ from onshore and offshore well sites, gas flaring, natural gas processing facilities, and natural gas compressor stations throughout Mexican basins. Crude oil storage tanks at onshore oil well sites $(63 \%)$ and venting and fugitive sources at offshore oil production sites $(28 \%)$ were the primary sources of VOC emissions. Natural gas and diesel-fired internal combustion engines at offshore oil well sites accounted for $55 \%-65 \%$ of $\mathrm{NO}_{\mathrm{x}}, \mathrm{CO}$, and $\mathrm{PM}_{2.5}$ emissions. Midstream operations represented $15 \%-21 \%$ of $\mathrm{NO}_{\mathrm{x}}$ and $\mathrm{CO}$ emissions. Onshore and offshore gas flaring (52\%) and natural gas-fired boilers and process heaters at natural gas processing facilities $(47 \%)$ accounted for almost all $\mathrm{SO}_{2}$ emissions. Identification of process and equipment configurations, temporal variations in emissions, super-emitting sources, and emission control implementation and effectiveness are ongoing needs for Mexico.

CAMx simulations identified geographic areas within Mexico and U.S. border states where emissions from oil and gas operations could contribute to MDA8 ozone and $24 \mathrm{~h}$ average PM2.5 concentrations. Among the source types and regions considered in this study, offshore oil well site operations in the Sureste Basin were the primary influence on air quality along the eastern coastline and other areas of Mexico and in Texas under favorable transport patterns. Exploration and development of Mexico's hydrocarbon resources could lead to changes in emissions profiles and air quality in the coming years.

Mexico has recently expressed its commitment to reducing greenhouse gas emissions but also to increasing oil production and refining capacity. Development of a photochemical modeling platform with high spatial granularity coupled with intensive surface and airborne measurements across Mexican basins would facilitate an improved understanding of the impacts of Mexico's future energy sector transitions. Top-down approaches that routinely use satellite retrievals can be used to track emissions and air quality trends in Mexico and U.S. border regions. Continued refinement of bottom-up emission inventories and coordinated atmospheric modeling can support the design of optimum emission control strategies for existing and future operations.

Supplementary Materials: The following are available online at https:/ / www.mdpi.com/article/10 .3390 /atmos12121696/s1, Figure S1: CAMx 36 km × 36 km horizontal modeling domain., Figure S2: Contributions to $\mathrm{NO}_{\mathrm{x}}, \mathrm{CO}, \mathrm{SO}_{2}, \mathrm{VOC}$, and PM2.5 emissions from onshore and offshore well sites, natural gas processing facilities, and flaring by basin, Figure S3: Locations of active 2016 oil and/or gas wells by basin and flaring in this study and oil and gas sector emission sources identified in the 2016v1 National Collaborative Emissions Modeling Platform, Figure S4: Predicted annual average and maximum differences in $24 \mathrm{~h} \mathrm{PM}_{2.5}$ concentrations by grid cell when emissions from offshore well sites in the Sureste Basin were zeroed relative to the 2016 base case, Figure S5: Predicted annual average differences and maximum differences in MDA8 ozone concentrations by grid cell when emissions from onshore well site operations in the Sureste, Tampico-Misantla, Veracruz, and Burgos and Sabinas basins and from midstream sources were zeroed relative to the 2016 base case. Table S1: Oil and gas activity metrics mapped to EPA emission source classification codes; Table S2: Emission factors for onshore oil and gas production well sites in the Sabinas and Burgos basins., Table S3: Emission factors for onshore oil and gas production well sites in the Sureste, Tampico-Misantla, and Veracruz basins, Table S4: Emissions per unit of production (lb/Mbbl/yr) from offshore oil and gas well sites, Table S5: Annual emissions of $\mathrm{CO}, \mathrm{NO}_{\mathrm{x}}, \mathrm{PM}_{2.5}, \mathrm{SO}_{2}$, and VOC from this study and the 2016v1 inventory for oil and gas exploration and extraction, natural gas processing facilities, and natural gas compressor stations.

Author Contributions: Conceptualization, E.M.-B. and G.Y.; Data curation, G.M. and J.G.; Formal analysis, E.M.-B., G.M. and J.G.; Funding acquisition, E.M.-B. and G.Y.; Investigation, E.M.-B., G.M., J.G., T.S. and Y.K.; Methodology, E.M.-B., G.M., J.G., T.S. and Y.K.; Project administration, E.M.-B.; Supervision, E.M.-B. and G.Y.; Visualization, G.M. and Y.K.; Writing-original draft, E.M.-B. and G.M.; Writing-review \& editing, E.M.-B., G.M., J.G., T.S., Y.K. and G.Y. All authors have read and agreed to the published version of the manuscript. 
Funding: Funding was provided by the National Science Foundation (Grant \#1638258). The research was also funded by a grant from the Texas Air Quality Research Program (AQRP Project 19-023) at The University of Texas at Austin through the Texas Emission Reduction Program (TERP) and the Texas Commission on Environmental Quality (TCEQ). The findings, opinions and conclusions are the work of the authors and do not necessarily represent findings, opinions, or conclusions of the AQRP or the TCEQ.

Institutional Review Board Statement: Not applicable.

Informed Consent Statement: Not applicable.

Data Availability Statement: The emission inventory is available in an AIRS Facility System (AFS) format upon request from the authors.

Acknowledgments: The authors thank Doug Boyer, Bright Dornblaser, Weining Zhao, and Khalid Al-Wali of the Texas Commission on Environmental Quality for their assistance with the 2016 CAMx modeling platform. The authors also express their appreciation to Heather Simon and Madeleine Strum of the U.S. EPA for assistance with the 2016v1 emissions modeling platform.

Conflicts of Interest: The authors declare no conflict of interest.

\section{References}

1. British Petroleum. BP Statistical Review of World Energy 2021, Consolidated Dataset. Available online: https://www.bp.com/ en/global/corporate/energy-economics/statistical-review-of-world-energy/downloads.html (accessed on 8 November 2021).

2. Wood, D.; Martin, J. Of Paradigm shifts and political conflict: The history of Mexico's second energy revolution. In Mexico's New Energy Reform; Wood, D., Ed.; Wilson Center Mexico Institute: Washington, DC, USA, 2018; pp. 17-35.

3. Sanchez, G.J.G. The fine print of the Mexican energy reform. In Mexico's New Energy Reform; Wood, D., Ed.; Wilson Center Mexico Institute: Washington, DC, USA, 2018; pp. 36-52.

4. OECD/IEA. Energy Policies Beyond IEA Countries: Mexico 2017. Paris, 2017. Available online: https://www.iea.org/reports/ energy-policies-beyond-iea-countries-mexico-2017 (accessed on 8 March 2018).

5. National Hydrocarbons Commission. Rondas Mexico Web Portal. Available online: https://rondasmexico.gob.mx (accessed on 29 July 2021).

6. International Trade Administration, U.S. Department of Commerce. Mexico-Country Commercial Guide: Oil and Gas. Available online: https:/ / www.trade.gov/country-commercial-guides/mexico-oil-and-gas (accessed on 8 November 2021).

7. Gross, S. AMLO Reverses Positive Trends in Mexico's Energy Industry, Brookings Institution, 20 December 2019. Available online: https: / / www.brookings.edu/blog/order-from-chaos/2019/12/20/amlo-reverses-positive-trends-in-mexicos-energyindustry/ (accessed on 15 January 2020).

8. IEA. Oil 2021 Analysis and Forecast to 2026. Available online: https:/ / www.iea.org/reports/oil-2021 (accessed on 4 November 2021).

9. Ministry of Environment and Natural Resources (SEMARNAT) and National Institute of Ecology and Climate Change (INECC). Nationally Determined Contributions; 2020 Update; SEMARNAT: Mexico City, Mexico; INECC: Mexico City, Mexico, 2020.

10. Diario Oficial de la Federación. Disposiciones Administrativas de Carácter General Que Establecen Los Lineamientos Para La Prevención y El Control Integral de las Emisiones de Metano del Sector Hidrocarburos. 2018. Available online: https: / /www.dof.gob.mx/nota_detalle.php?codigo=5543033\&fecha=06/11/2018 (accessed on 8 February 2021).

11. European Commission. Launch by United States, the European Union, and Partners of the Global Methane Pledge to Keep 1.5C Within Reach. Available online: https:/ / ec.europa.eu/commission/presscorner/detail/en/statement_21_5766 (accessed on 4 November 2021).

12. Michanowicz, D.R.; Lebel, E.D.; Domen, J.K.; Hill, L.A.L.; Jaeger, J.M.; Schiff, J.E.; Krieger, E.M.; Banan, Z.; Goldman, J.S.W.; Nordgaard, C.L.; et al. Methane and Health-Damaging Air Pollutants from the Oil and Gas Sector: Bridging 10 Years of Scientific Understanding; PSE Technical Report; PSE: Oakland, CA, USA, 2021.

13. Francoeur, C.B.; McDonald, B.C.; Gilman, J.B.; Zarzana, K.J.; Dix, B.; Brown, S.S.; de Gouw, J.A.; Frost, G.J.; Li, M.; McKeen, S.A.; et al. Quantifying Methane and Ozone Precursor Emissions from Oil and Gas Production Regions across the Contiguous US. Environ. Sci. Technol. 2021, 55, 9129-9139. [CrossRef] [PubMed]

14. Kemball-Cook, S.; Bar-Ilan, A.; Grant, J.; Parker, L.; Jung, J.; Santamaria, W.; Mathews, J.; Yarwood, G. Ozone impacts of natural gas development in the Haynesville Shale. Environ. Sci. Technol. 2010, 44, 9357-9363. [CrossRef] [PubMed]

15. Thompson, T.M.; Shepherd, S.; Stacy, A.; Barna, M.G.; Schichtel, B.A. Modeling to Evaluate Contribution of Oil and Gas Emissions to Air Pollution. J. Air Waste Manag. Assoc. 2017, 67, 445-461. [CrossRef] [PubMed]

16. Rodriguez, M.A.; Barna, M.G.; Moore, T. Regional Impacts of Oil and Gas Development on Ozone Formation in the Western United States. J. Air Waste Manag. Assoc. 2009, 59, 1111-1118. [CrossRef]

17. USEPA. Integrated Science Assessment (ISA) for Oxides of Nitrogen-Health Criteria (Final Report, 2016); EPA/600/R-15/068, 2016; U.S. Environmental Protection Agency: Washington, DC, USA, 2016. 
18. USEPA. Integrated Science Assessment (ISA) for Sulfur Oxides_Health Criteria (Final Report, 2017); EPA/600/R-17/451, 2017; U.S. Environmental Protection Agency: Washington, DC, USA, 2017.

19. USEPA. Integrated Science Assessment (ISA) for Carbon Monoxide (Final Report, 2010); EPA/600/R-09/019F; U.S. Environmental Protection Agency: Washington, DC, USA, 2010.

20. USEPA. Integrated Science Assessment (ISA) for Particulate Matter (Final Report, 2019); EPA/600/R-19/188; U.S. Environmental Protection Agency: Washington, DC, USA, 2019.

21. USEPA. Integrated Science Assessment (ISA) for Oxides of Nitrogen, Oxides of Sulfur and Particulate Matter Ecological Criteria (Final Report, 2020); EPA/600/R-20/278; U.S. Environmental Protection Agency: Washington, DC, USA, 2020.

22. USEPA. Integrated Science Assessment (ISA) for Ozone and Related Photochemical Oxidants (Final Report, April 2020); EPA/600/R20/012; U.S. Environmental Protection Agency: Washington, DC, USA, 2020.

23. Gonzalez, D.J.X.; Sherris, A.R.; Yang, W.; Stevenson, D.K.; Padulac, A.M.; Baiocchi, M.; Burkee, M.; Cullen, M.R.; Shaw, G.M. Oil and gas production and spontaneous preterm births in the San Joaquin Valley, CA. Environ. Epidemiol. 2020, 4, e099. [CrossRef]

24. Johnston, J.E.; Limb, E.; Ro, H. Impact of upstream oil extraction and environmental public health: A review of the evidence. Sci. Total Environ. 2019, 657, 187-199. [CrossRef]

25. McKenzie, L.M.; Blair, B.; Hughes, J.; Allshouse, W.B.; Blake, N.J.; Helmig, D.; Milmoe, P.; Halliday, H.; Blake, D.R.; Adgate, J.L. Ambient Nonmethane Hydrocarbon Levels Along Colorado's Northern Front Range: Acute and Chronic Health Risks. Environ. Sci. Technol. 2018, 52, 4514-4525. [CrossRef]

26. McKenzie, L.M.; Crooks, J.; Peel, J.L.; Blair, B.D.; Brindley, S.; Allshouse, W.B.; Malin, S.; Adgate, J.L. Relationships between indicators of cardiovascular disease and intensity of oil and natural gas activity in Northeastern Colorado. Environ. Res. 2019, 170, 56-64. [CrossRef]

27. Garcia-Gonzales, D.A.; Shonkoff, S.B.C.; Hays, J.; Jerrett, M. Hazardous Air Pollutants Associated with Upstream Oil and Natural Gas Development: A Critical Synthesis of Current Peer-Reviewed Literature. Annu. Rev. Public Health 2019, 40, 283-304. [CrossRef]

28. Webb, E.; Hays, J.; Dyrszka, L.; Rodriguez, B.; Cox, C.; Huffling, K.; Bushkin-Bedient, S. Potential hazards of air pollutant emissions from unconventional oil and natural gas operations on the respiratory health of children and infants. Rev. Environ. Health 2016, 31, 225-243. [CrossRef]

29. Tran, K.V.; Casey, J.A.; Cushing, L.J.; Morello-Frosch, R. Residential Proximity to Oil and Gas Development and Birth Outcomes in California: A Retrospective Cohort Study of 2006-2015 Births. Environ. Health Perspect. 2020, 128, 67001. [CrossRef]

30. Willis, M.D.; Hill, E.L.; Boslett, A.; Kile, M.L.; Carozza, S.E.; Hystad, P. Associations between Residential Proximity to Oil and Gas Drilling and Term Birth Weight and Small-for-Gestational-Age Infants in Texas: A Difference-in-Differences Analysis. Environ. Health Perspect. 2021, 129, 077002. [CrossRef]

31. Gamboa, R.T.; Gamboa, A.R.; Bravo, A.H.; Ostrosky, W.P. Genotoxicity in child populations exposed to polycyclic aromatic hydrocarbons (PAHs) in the air from Tabasco, Mexico. Int. J. Environ. Res. Public Health 2008, 5, 349-355. [CrossRef]

32. Nwosisi, C.; Oguntoke, O.; Taiwo, A.M.; Agbozu, I.E.; Noragbon, E.J. Spatial patterns of gas flaring stations and the risk to the respiratory and dermal health of residents of the Niger Delta, Nigeria. Sci. Afr. 2021, 12, e00762. [CrossRef]

33. Shamasunder, B.; Collier-Oxandale, A.; Blickley, J.; Sadd, J.; Chan, M.; Navarro, S.; Hannigan, M.; Wong, N.J. Community-Based Health and Exposure Study around Urban Oil Developments in South Los Angeles. Int. J. Environ. Res. Public Health 2018, 15, 138. [CrossRef]

34. Villaseñor, R.; Magdaleno, M.; Quintanar, A.; Gallardo, J.C.; López, M.T.; Jurado, R.; Miranda, A.; Aguilar, M.; Melgarejo, L.A.; Palmerín, E.; et al. An air quality emission inventory of offshore operations for the exploration and production of petroleum by the Mexican oil industry. Atmos. Environ. 2003, 37, 3713-3729. [CrossRef]

35. Schifter, I.; González-Macías, C.; Miranda, A.; López-Salinas, E. Air emissions assessment from offshore oil activities in the Sonda de Campeche. Mexico. Environ. Monit. Assess. 2005, 109, 135-145. [CrossRef]

36. Mendoza-Domínguez, A.; Graniel-Peralta, M. Estimacíon de emisiones a la atmósfera provenientes de quemadores elevados de instalaciones petroleras en la Sonda de Campeche. Ing. Investig. Technol. 2006, 3, 165-173. [CrossRef]

37. Bauer, M.; Melgar, E.; Villaseñor, R.; Magdaleno, M.; Elizalde, A.; Mar, E.; Ceballos, E.; Yáñez, G.; Martínez, S.; Tavera, L.; et al. Technical-Economical analysis of the environmental impact and corresponding sustainability indicators of the use of natural gas in Mexico. In Proceedings of the 22nd World Gas Conference, Tokyo, Japan, 4 June 2003.

38. Muriel-García, M.; Cerón-Bretón, R.M.; Cerón-Bretón, J.G. Air pollution in the Gulf of Mexico. Open J. Ecol. 2016, 6, 32-46. [CrossRef]

39. US EPA. 2016v1 Emissions Modeling Platform. Available online: www.epa.gov/air-emissions-modeling/2016v1-platform (accessed on 4 December 2018).

40. National Hydrocarbons Commission Oil and Gas Statistics Dashboard. Available online: https://sih.hidrocarburos.gob.mx/ (accessed on 17 April 2019).

41. Sandrea, R. Understanding the Challenges to Mexico's Oil \& Gas Future. Available online: https://eprinc.org/wp-content/ uploads/2019/07/Sandrea-Mexico-Paper-July-2019-FINAL-1.pdf (accessed on 24 September 2020).

42. Petróleos Mexicanos. Statistical Yearbook. 2016. Available online: https://www.pemex.com/en/investors/publications/ Paginas/statistical-yearbook.aspx (accessed on 22 July 2019).

43. IEA. The Distribution of U.S. Oil and Natural Gas Wells by Production Rate; Department of Energy: Washington, DC, USA, 2020. 
44. US EPA. National Emission Inventory v2 (NEI 2014v2), 2018a. Available online: https:/ / www.epa.gov/air-emissions-inventories / 2014-national-emissions-inventory-nei-data (accessed on 8 August 2019).

45. US EPA. Oil and Gas Emission Estimation Tool, 2014 NEI v.2.1—Production Activities Module; US EPA: Washington, DC, USA, 2017.

46. Wilson, D.; Billings, R.; Chang, R.; Enoch, S.; Do, B.; Perez, H.; Sellers, J. Year 2014 Gulfwide Emissions Inventory Study; Eastern Research Group (BOEM Contract M13PC00005): Morrisville, NC, USA, 2017.

47. Bureau of Ocean and Energy Management Data Center. Available online: https://www.data.boem.gov/Main/Production.aspx (accessed on 19 January 2019).

48. Shah, T.; Parker, L.; Grant, J.; Yarwood, G. Modeling Inventories for Mexico and Caribbean Countries to Support Quantitative Analysis of International Transport Impacts on Ozone Design Values and Regional Haze; Ramboll (Texas Commission on Environmental Quality Contract No. 582-15-50417): Novato, CA, USA, 2018.

49. US EPA. AP-42 Compilation of Emission Factors. Available online: https://www.epa.gov/air-emissions-factors-andquantification/ap-42-compilation-air-emissions-factors (accessed on 25 February 2019).

50. Colorado School of Mines Earth Observation Group. VIIRS Nightfire Global Gas Flaring Data Portal. Available online: https: / / payneinstitute.mines.edu/eog/viirs-nightfire-vnf/ (accessed on 3 July 2020).

51. Eastern Research Group. Develop Mexico Future Year Emissions; Eastern Research Group (US EPA Contract No. EP-D-11-006): Sacramento, CA, USA, 2014.

52. North American Cooperation on Energy Information. Infrastructure Map Natural Gas Processing Plants. Available online: http:/ /nacei.org/\#!/maps (accessed on 9 April 2018).

53. National Hydrocarbons Commission. Natural Gas Infrastructure Map. Available online: https://mapa.hidrocarburos.gob.mx (accessed on 17 July 2019).

54. Secretary of Energy Mexico. Prospectiva de Gas Natural y Gas L.P. 2013-2027. Available online: https://www.gob.mx/cms/ uploads/attachment/file/62950/Prospectiva_de_Gas_natural_y_Gas_L.P._2013-2027.pdf (accessed on 17 July 2019).

55. Eduardo, D.S. Comercializacion y Distribucion de Gas Natural en Mexico. Ph.D. Thesis, Universidad Nacional Autónoma de México, Ciudad Universitaria, Mexico City, Mexico, November 2018.

56. Texas Commission on Environmental Quality. Revisions to the State of Texas Air Quality Implementation Plan for the Control of Regional Haze; Project Number 2019-112-SIP-NR; Texas Commission on Environmental Quality: Austin, TX, USA, 2020.

57. Ramboll. Comprehensive Air Quality Model with Extensions. Available online: https://www.camx.com (accessed on 5 October 2020).

58. McDonald-Buller, E.; McGaughey, G.; Shah, T.; Grant, J.; Kimura, Y.; Yarwood, G. Mexico's electricity grid and fuel mix: Implications of a fifteen-year planning horizon on emissions and air quality. Environ. Res. Lett. 2021, 16, 074050. [CrossRef]

59. Crippa, M.; Oreggioni, G.; Guizzardi, D.; Muntean, M.; Schaaf, E.; Lo Vullo, E.; Solazzo, E.; Monforti-Ferrario, F.; Olivier, J.G.J.; Vignati, E. Fossil $\mathrm{CO}_{2}$ and GHG Emissions of all World Countries-2019 Report, EUR 29849 EN; Publications Office of the European Union: Luxembourg, 2019; JRC117610. [CrossRef]

60. Crippa, M.; Solazzo, E.; Huang, G.; Guizzardi, D.; Koffi, E.; Muntean, M.; Schieberle, C.; Friedrich, R.; Janssens-Maenhout, G. High resolution temporal profiles in the Emissions Database for Global Atmospheric Research (EDGAR). Sci. Data 2019, 7, 1-17. [CrossRef]

61. Crippa, M.; Guizzardi, D.; Muntean, M.; Schaaf, E.; Dentener, F.; van Aardenne, J.A.; Monni, S.; Doering, U.; Olivier, J.G.J.; Pagliari, V.; et al. Gridded emissions of air pollutants for the period 1970-2012 within EDGAR v4.3.2. Earth Syst. Sci. Data 2018, 10, 1987-2013. [CrossRef]

62. Crippa, M.; Guizzardi, D.; Muntean, M.; Schaaf, E.; Oreggioni, G. EDGAR v5.0 Global Air Pollutant Emissions. European Commission, Joint Research Centre (JRC) [Dataset]. 2019. Available online: http://data.europa.eu/89h/377801af-b094-49438fdc-f79a7c0c2d19 (accessed on 17 February 2021).

63. Zhang, Y.; Gautam, R.; Zavala-Araiza, D.; Jacob, D.; Zhang, R.; Zhu, L.; Sheng, J.-X.; Scarpelli, T. Satellite Observed Changes in Mexico's Offshore Gas Flaring Activity Linked to Oil/Gas Regulations. Geophys. Res. Lett. 2019, 46, 1879-1888. [CrossRef]

64. ICF International. Economic Analysis of Methane Emission Reduction Opportunities in the Mexican Oil and Natural Gas Industries; ICF International: Fairfax, VA, USA, 2015; Available online: https://www.edf.org/sites/default/files/content/mexico_methane_ cost_curve_report.pdf (accessed on 19 February 2021).

65. Fioletov, V.E.; McLinden, C.A.; Krotkov, N.; Yang, K.; Loyola, D.G.; Valks, P.; Theys, N.; van Roozendael, M.; Nowlan, C.R.; Chance, K.; et al. Application of OMI, SCIAMACHY, and GOME-2 satellite $\mathrm{SO}_{2}$ retrievals for detection of large emission sources. J. Geophys. Res. 2013, 118, 11,399-11,418. [CrossRef]

66. Zavala-Araiza, D.; Omara, M.; Gautum, R.; Smith, M.I.; Sudhanshu, P.; Aben, I.; Almanza-Veloz, V.; Conley, S.; Houweling, S.; Kort, E.A.; et al. A tale of two regions: Methane emissions from oil and gas production in offshore/onshore Mexico. Environ. Res. Lett. 2021, 16, 024019. [CrossRef]

67. Banerjee, S.; Toledano, P. A Policy Framework to Approach the Use of Associated Petroleum Gas, Staff Publication 7-2016; Columbia Center on Sustainable Investment: New York, NY, USA, 2016.

68. Toledano, P.; Archibong, B. Mexico Associated Gas Utilization Study; Columbia Center on Sustainable Investment: New York, NY, USA, 2016; Available online: https:/ /ccsi.columbia.edu/sites/default/files/content/docs/our\%20focus/Mexico-APGUtilitzation-Study-July-2016-CCSI.pdf (accessed on 10 January 2019). 
69. Torres, V.M.; Herndon, S.; Kodesh, Z.; Allen, D.T. Industrial flare performance at low flow conditions: Part 1. Study overview. Ind. Eng. Chem. Res. 2012, 51, 12559-12568. [CrossRef]

70. Torres, V.M.; Herndon, S.; Allen, D.T. Industrial flare performance at low flow conditions: Part 2. Air and steam assisted flares. Ind. Eng. Chem. Res. 2012, 51, 12569-12576. [CrossRef]

71. Pavlovic, R.T.; Al-Fadhli, F.M.; Kimura, Y.; Allen, D.T.; McDonald-Buller, E.C. Impacts of emission variability and flare combustion efficiency on ozone formation in the Houston-Galveston-Brazoria area. Ind. Eng. Chem. Res. 2012, 51, 12593-12599. [CrossRef]

72. Herndon, S.; Nelson, D.D., Jr.; Wood, E.C.; Knighton, W.B.; Kolb, C.E.; Kodesh, Z.; Torres, V.M.; Allen, D.T. Application of the carbon balance method to flare emissions characteristics. Ind. Eng. Chem. Res. 2012, 51, 12577-12585. [CrossRef]

73. Al-Fadhli, F. Impact of Flare Destruction Efficiencies on Ozone Concentrations: A case study for Houston, Texas. Master's Thesis, University of Texas at Austin, Austin, TX, USA, May 2010.

74. Talos Energy Mexico. Available online: https://www.talosenergy.com/operations/mexico/default.aspx (accessed on 17 November 2021). 